\title{
Critical Skills for Computer Academicians Course Proposal
}

\author{
Muhammad Shaheen and Zahoor Ur Rehman \\ University of Engineering \& Technology, Lahore, Pakistan
}

\author{
shaheentanoli@gmail.com xahoor@gmail.com
}

\begin{abstract}
The numbers of Computer Science professionals are rapidly increasing in Pakistan. Earlier revisions of the CS curriculum made by Higher Education Commission (HEC), Pakistan were based upon the critical skills needed for the professionals according to the demands of market. Unfortunat ely no effort was made to determine the critical skills needed for computer academicians. As part of the course development process for academicians, a study was conducted to determine the expected skills and knowledge required for these academicians. The academicians are divided into three main groups: Computer Programming instructors, Dat abases Instructors and Computer Networks instructors. These groups were made after the survey of demand from IT industry in Pakistan. It was concluded from the survey that More than 65\% Computer professional jobs are required for the mentioned groups. An online survey tool (http://www.qnaire.netfirms.com) was developed to collect the dat a from respondents about the importance of various skills for computer science academicians. Ph.D professors, Ph.D Assistant Professors and Lecturers having Bachelors degree in Computer Science or relevant discipline are included in the list of respondents. The results indicate that the conceptual knowledge about three groups will be important with handsome emphasis on advanced applications. By applying principal component analysis and correlation analysis on the data collected by online survey the prominent factors were identified on the basis of which a course plan was developed. In coming years the better results will produce by the proposed curriculum.
\end{abstract}

Keywords: curriculum development, computer academician, programming instructors, database instructors, networks instruct ors, teaching assistants.

\section{Introduction}

The number of workers in the computer software industry has been increased three times as compared to the past decade (Freeman \& Aspray, 1999, p. 35). The skills that are needed to be successful in the field of Computer Science are constantly changing. The Researchers showed a lot of interest to find the gap between expected level of skills and observed level of skills once a person has been hired. Cappel's research showed that the development of programming skills re-

Material published as part of this publication, either on-line or in print, is copyrighted by the Informing Science Institute. Permission to make digital or paper copy ofpart or all of these works for personal or classroomuse is granted without fee provided that the copies are not made or distributed for profit or commercial advantage AND that copies 1 ) bear this notice in full and 2) give the full citation on the first page. It is permissible to abstract these works solong as credit is given. To copy in all other cases orto republish or to post on a serveror to redistribute to lists requires specific permission and payment ofa fee.Contact Publisher@.InformingScience.org to request redistribution permission. mained an essential component for Computer professionals (Cappel, 2002, p. 76-82). Byrd research indicates that besides technical skills, managerial, business and interpersonal skills have also become increasingly cited for these professionals (Byrd \& T urner, 2001 p.21-55). Liu focused on the technical skills necessary for entry-level professionals. Examination of Monster.com 
and Hot Jobs.com technical skill requirements over a 10 -week period revealed much greater demand for contemporary programming languages and Web-development skills and less demand for traditional programming skills (Liu, Kiu, Koong, \& Lu, 2003, pp.191-196). Hingorani and Sankar acquired student and industry perceptions of twenty skills required of new MIS (Management Information System) hires in the Information Systems industry. Results of a comparison of perceptions indicate that the student and the industry rankings differ. Students perceived "problem solving" as the number one skill of an IS professional, while the industry ranked it at six. Likewise, the industry ranked system analysis and design as the most important skill, while the students ranked it at number six. The broad skill of business communication and interpersonal relations was given a number two ranking by both the students and industry (Hingorani \& Sankar, 1995). Gerald F. Braun identified critical skills for Computer Professionals after taking responses from Managers and IT professionals through an ASP based online survey tool. The survey measured entry level IT/IS skill expectations and employer satisfaction with knowledge/ skills possessed by recent hires. The curriculum which is necessary to train an academician so that these skills can efficiently be transferred to the graduates is addressed in this research (Braun, Tesch, \& Skeldon, 2005).

Pakistan is one of the developing countries and Higher Education Commission in Pakistan has taken sound measures for advancement of higher education in the last five years. Computer Science is one of the major domains focused by HEC in this period.

Government of Pakistan, finalized IT policy in 2004 in which it was quoted that Human Resource (HR) Development is imperative for the local IT industry to upgrade the country as an important player in the international IT market. Under the HR Action Plan, a large pool of academically as well as technically skilled IT manpower would be developed to meet the local and export demands. The Policy accordingly envisaged the establishment of four new IT Universities, Virtual IT University, National Testing and Accreditation Services and Educational Intranet, strengthening of existing IT Institutes and hiring of Faculty from abroad. A major portion of the funds under IT Action Plan would be dedicated towards HR development initiatives (Ministry of Information Technology, Pakistan, 2004).

The soft ware industry in Pakistan is not much advanced and relies on the use of old technologies and methodologies due to unavailability of the required professionals. There is a gap between the education provided to computer professionals and the needs of soft ware industry.

Limbie Kelegai and Michael Middleton (2002) described that computer systems and soft ware are rapidly becoming outdated, subsequently making an individual's knowledge quickly obsolete.

Policy makers generally considered the education system as the vehicle by which IT professionals are trained and prepared to meet industry needs. Emphasis is now placed on educational system to produce IT professionals to meet the demands of the changing workplace. Third world countries have been slower in realizing the significance of human resources development, in particular for IT, in order to become a part of the global context. So it is the responsibility of the academician to guide the student about research and development and to adopt new technology in an efficient manner.

(IEEE-CS) and the Association for Computing Machinery (ACM) Computing Curricula 2001 (CC2001) consist of five volumes; Vol. 1 Overview, Vol. 2 Computer Science, Vol. 3 Computer Engineering, Vol. 4 Software Engineering, and Vol. 5 Information Systems in which abilities and skills essential for IT resource person are mentioned. It is advised to focus on following;

- Cognitive abilities and skills relating to intellectual tasks specific to computer science

- Practical skills relating to computer science 
- Additional transferable skills that may be developed in the context of computer science but which are of a general nature and applicable in many other contexts as well.

Srinivasan, Guan, and Wright (1999) describe a process of developing a new curriculum working with corporate partners. They also suggest using the corporate partners as "clinical": faculty to help teach the courses. Trauth reported that the computer professionals in fut ure would also be responsible to lead organizational IS for which they will need to have managerial, business operations and interpersonal skills along with technological skills (Trauth et.al, 1999). Maier Clark and Remington (1998) surveyed the job advertisements for a period of 15 years to explore the changes in IT job market. Maglitta in Computerworld reported that academicians and IS managers are dissatisfied with the technical, business, industry and soft skills of IS professionals. They criticized the knowledge of graduates on hot technologies like Telecommunications, RDBMS, project management, communication, documentation, e-commerce, business process reengineering and team skills (Maglitta, 1996). Cheryl L. Noll and Marilyn Wilkins (2002) fashioned a questionnaire including the questions of IS knowledge, programming, platforms/ operat ing systems applications, networking and database software, business functional knowledge and interpersonal and management skills. The importance of each skill was elicited from staffing groups in order to define a set of critical skills. Most of the rated critical skills in this research are extracted from the work of Cheryl L. Noll. Barbara J. Nicolai presented successful IT curriculum with accreditation point of view. This curriculum is very much suitable for identifying the needed skills of IT professionals (Nocolai, 2004). Stuart specified interest scales, aptitude and achievement test $\mathrm{s}$ as cognitive predict ors of success in Computer programmer training. His research was hypothesized on the relationships between programmer trainee performance and inferential ability, programmer trainee performance and deductive ability, programmer trainee performance and interpret ive ability, programmer trainee performance and general mathemat ics ability, programmer trainee performance and ability to recognize and apply the implied rules and basic assumptions (Jacobs, 1973).

Yongbeom Kim identified 30 key Information system issues after conducting a survey of IS practitioners and educators regarding the perceived importance. The survey results showed that the two groups perceive differently the relative importance of twelve IS issues, while they agree on the relative import ance of the remaining eighteen IS issues. Based upon the results, Kim suggested specific guidelines for effective implementation of IS curriculum by attempting to bridge the gap between practitioner-educator perceptions of IS issues (Yongbeom, 1999).

These factors will be useful for preparing a preparat ory course structure for computer academicians.

Higher Education Commission (HEC) Pakistan proposed detailed curriculum for BS (Computer Sciences) in 2004. The curriculum included core courses of 37 credit hours, supporting sciences of 12 credit hours and general education of 15 credit hours (2004). The detailed curriculum is available at http://www.hec.gov.pk. This curriculum was useful for getting information about focused studies in BS (Computing).

Ruth A. Miller and Donna W. Luse (2004) focused on communication and collaborative skills, which are critical for IS staff for system development.

Computer Skills growth chart is presented by InstructionalT echnology Guiding Rigorous Academic and Teaching Excellence (INT EGRATE) a working group of Delaware center for Educational Technology (DCET) (2005). The computer skills in this research are divided into five sections, Email \& Internet, Network \& computing skills, word processing, Graphics and databases. The critical skills for each section are identified separately. 
A number of efforts have been made to highlight the guidelines needed for curriculum development or for identification of critical fact ors for the students of computer sciences. The skills which are critical for computer academicians can be derived from this literat ure. In this paper a study is reported, that was conducted to determine the critical skills for a computer academician. Computer academicians were divided into two groups: subject specialists and teaching assistants. The IT industry in Pakistan is in demand of Computer programmers, Database professionals and Network Engineers so this study was further focused to the subject specialists of these three areas. In particular these questions were addressed.

- What are the critical skills for subject specialists in the sub-domains of computer sciences?

- A pre-service course should be offered to subject specialists. How should this course be structured? The curriculum of course can be offered in extension of this work.

- What are the critical skills for teaching assistants?

- A pre-service course should be offered to teaching assistants. How should this course be prepared?

\section{Research Methods}

The literatures from the domain of Computer Sciences as well as recent research efforts made (as mentioned in the above section) are extensively researched to find out import ant factors with respect to academician as well as student point of view. We mentioned earlier about the gap between the education provided to computer professional and the needs of software industry as well as computer academia. To fill this gap, one way is to address the student curriculum which has been frequently changing for last three decades. Another way is to provide training to computer academicians who then teach the students as per normal accredited syllabus specifically focusing upon the key areas of these three domains i.e. Programming, Databases and Networking. The key areas with the associated weights will be specified later in the paper. An online questionnaire was prepared on the basis of literat ure review and interviews with professors, assistant professors, associate professors, lecturers from a number of IT -based universit ies in Pakistan, database managers, IT managers, senior soft ware developers and System Analysts. The questionnaire was uploaded at free sub-domain (URL of questionnaire). An email was sent to all the respondents for requesting them to complete the online questionnaire. This email was also sent to the Chairman, National Computing Education Accreditation Council (NCEAC) Pakistan and other members of NCEAC. The questionnaire was sent to a total number of 180 academicians, 16 administrators, 20 members from concerned authorities working under Higher Education Commission (HEC) and 30 members from soft ware industry. All the universities and graduate institutes in Pakistan took charter from HEC and secondly HEC is very much interested in improvement of graduate education in Pakistan for which they established accreditation council, quality assurance agencies and awarded scholarships to students as well as to various faculty members for acquiring technical and professional diplomas as well as degrees in the last few years (http://www.hec.gov.pk). So it was necessary to take the opinion of authorities of HEC before designing such a course for academicians. The online survey has mainly been targeted for academicians in education sector because the response for software/IT industry was not so appropriate. As the jobs or the work allocated to industry personnel is objective oriented so they were unable to comment on a broad domain of Computer sciences. Even, the questionnaire was divided into parts so that the database relevant questions should be responded by database professionals, programming relevant questions by programmers and so on. But the interviews revealed that they were not even able to respond questions from a broad domain of database management and computer programming due to limited scope of their job, very much specific set of responsibilities and lack of intellectual abilities. As a result, the responses from academic institutes were considered only for getting ap- 
propriate results. Fifty five questionnaires were returned. The questionnaire was designed in such a way that all of the responses were usable aggregating 31\% (approx) response rate. All of the $\mathrm{PhD}$ academicians responded in this regard was at the list of $\mathrm{HEC}$ recognized supervisors for $\mathrm{PhD}$ studies. A few of non-respondents experts were interviewed. Some respondents were also interviewed. This interview was base d upon two grounds: accuracy of the designed questionnaire, questions listed in the questionnaire.

\section{Design of Questionnaire}

The questionnaire was designed in such a way that the respondent might feel it convenient to go through. All the questions were scaled on 1-10 scale in an objective manner, where 1 represented the least while 10 represented the most critical value. For example, "Importance of analytical Skills" is questioned to the respondents and the response was taken on a scale made with the help of radio buttons on webpage.

\section{$\mathbb{E}_{1} \mathrm{C}_{2} \mathrm{C}_{3} \mathrm{C}_{4} \mathrm{C}_{5} \mathrm{C}_{6} \mathrm{C}_{7} \mathrm{C}_{8} \mathrm{C}_{9} \mathrm{C}_{10}$}

Where 1 means that the analytical skills are least critical. The increase in scale represents the increase in level of criticality, ending at 10, representing the highest critical value.

The questionnaire was divided in three sections.

- Critical Skills for Programming Instructors

- Critical Skills for Instructors of Databases

- Critical Skills for Instructors of Computer Networks

\section{Results}

First of all, following personal information about respondents was collected: Full Name, Designation, Qualification, University/Inst itute, Email address, Contact Number, age, experience, Areas of Expertise. (See Table 1.)

Some of sub-domains of Computer Sciences were included in the list of expertise which reflected that the participation of personnel from these sub-domains is more appreciable and useful. These sub-domains included Programming, Databases, Networks, Simulation \& Data Modeling, Software Engineering, Electronics, Computer Engineering relevant, Theoretical Computat ions, Operating Systems, Algorithms, Planning Sciences, Business IT and Statistics on Data. Of the fifty five respondents, eight een were Ph.D Professors/ Associate Professors/ Assistant Professors, twelve were non-Ph.D Professors/ Associate Professors/ Assistant Professors, thirteen were Lecturers and twelve were in non-teaching staff (administrators, HEC resource persons) in wellreputed universities and colleges in Pakistan. All ofthe included institutions enjoy a good reputation in computer education and are having the most competent and experienced faculty members. Higher Education Commission in Pakistan ranked these universities/colleges in Class " $A$ " which contain resource-wise rich institutions (2004). The criteria for evaluation of these universities/instit utions before adding them to a specific class, is uploaded on the website of HEC (http://www.hec.gov.pk). The faculties of university/institution bear good weight- age in the mentioned criterion. 


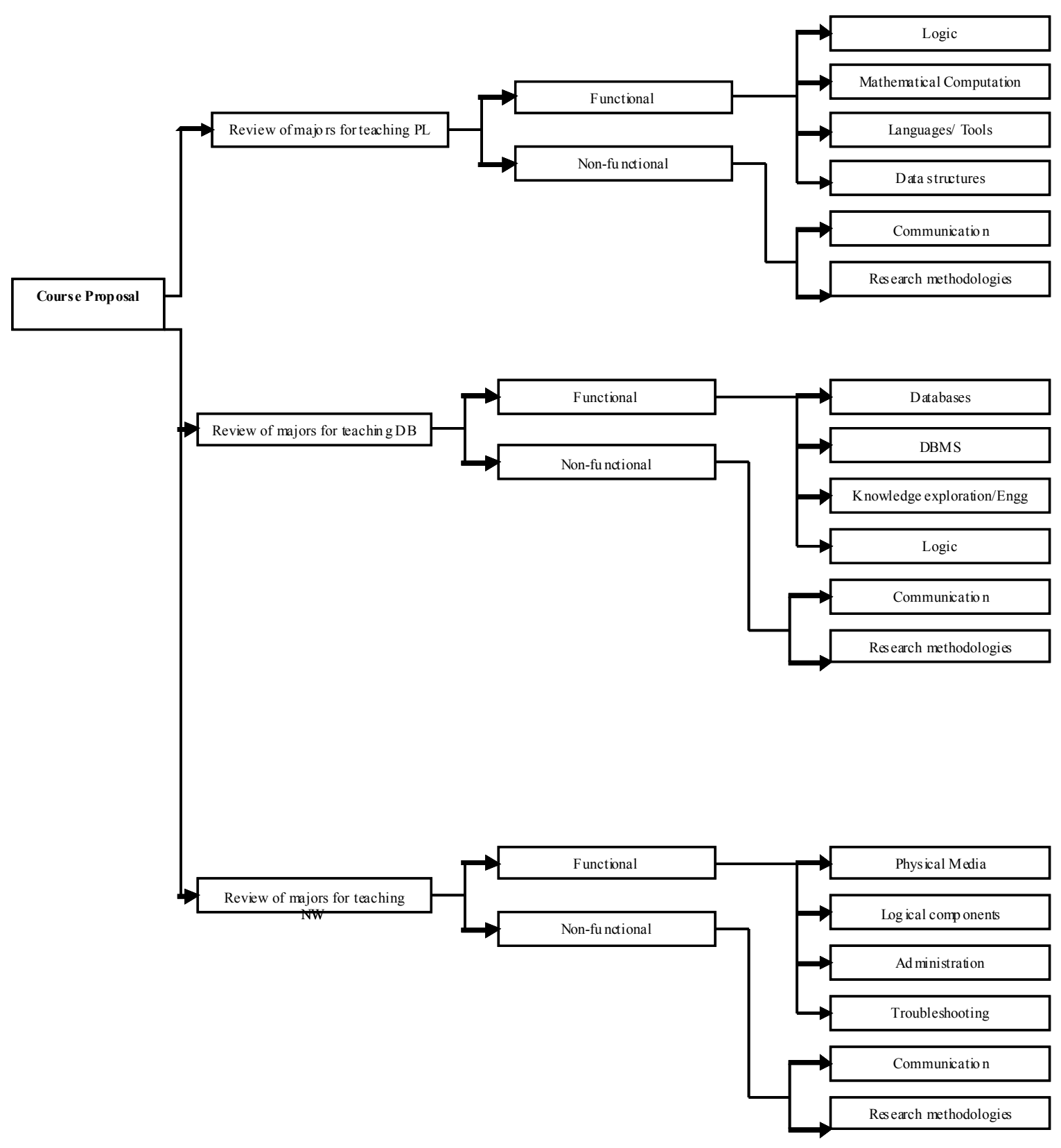

Figure 1- Critical skill evaluation model 


\begin{tabular}{|c|c|c|}
\hline \multicolumn{3}{|c|}{ TAB LE 1. DEMO GRAPHIC CHARAC TERIS TICS OF RESPONDENTS } \\
\hline TOTAL & MALE & FEMALE \\
\hline 55 & 52 & 3 \\
\hline Mean:3 & \multicolumn{2}{|c|}{ Standard Deviation: 8.3} \\
\hline EXP ER IENC E: & \multicolumn{2}{|c|}{ Standard Deviation: 5.7} \\
\hline DO MAIN-W ISE & & \\
\hline Programming & & 5 \\
\hline Databases & & 8 \\
\hline Networks & & 3 \\
\hline Simulation \& Data Modeling & & 2 \\
\hline Software Engg & & 7 \\
\hline Electronics & & 2 \\
\hline Computer Engg & & 3 \\
\hline Theoretical computations & & 1 \\
\hline Operating systems & & 4 \\
\hline Algorithms & & 1 \\
\hline Planning Sciences & & 1 \\
\hline Business IT & & 2 \\
\hline Statistics on data & & 4 \\
\hline
\end{tabular}

The results extracted from various academicians are analyzed through SPP (software developed for prediction) to extract the principal components of acquired data. In short the data is analyzed with the help of principal component analysis by taking mean value of frequency of each skill mentioned by academicians. This value is subtracted from individual frequencies. The covariance matrix is designed on the basis of extracted covariance. Since, the covariance matrix was a square matrix so the eigenvalue and eigenvectors are identified before extracting principal components. The detailed step-by-step elaboration of principal component analysis is available in a tutorial by Lindsay I. Smith (Lindsay, 2002).

After extracting the principal components, critical value for each of the principal component was evaluated. Those values were considered to be critical where the variance of eigenvalue was greater than or equal to 0.70 . The factors are ranked on the basis of these values. Table 2 depicts the critical values of skills.

\begin{tabular}{||l|l|l||}
\hline \multicolumn{1}{|c|}{ Table 2. Skills with their le vel of criticality } \\
\hline \multicolumn{1}{|c|}{ S.No } & \multicolumn{1}{|c||}{ Skill } & $\begin{array}{c}\text { Critical } \\
\text { Value }\end{array}$ \\
\hline Programming Instru ctors & 0.692 \\
\hline 1. & Skills of Commercial Programming & $\mathbf{0 . 8 4 2}$ \\
\hline 2. & Mathemat ical Computations & 0.680 \\
\hline 3. & Analytical Skills & 0.238 \\
\hline 4. & Spoken Language Skills & $\mathbf{0 . 8 2 2}$ \\
\hline 5. & Knowledge of Data Struct ures and mapping & $\mathbf{0 . 8 0 2}$ \\
\hline 6. & Pseudo code development & 0.550 \\
\hline 7. & Concepts of Language compilers/ Interpreters/ Assemblers & 0.524 \\
\hline 8. & Historical evolution of different programming languages & $\mathbf{0 . 8 8 8}$ \\
\hline 9. & Knowledge of Programming constructs & \\
\hline
\end{tabular}




\begin{tabular}{|c|c|c|}
\hline 10. & Knowledge of Requirement elicitation & 0.702 \\
\hline 11. & Knowledge of program testing under various factors & 0.664 \\
\hline 12. & Theory of automata (Implement at ion point of view) & 0.564 \\
\hline 13. & Limit ations of programming languages & 0.420 \\
\hline 14. & Comprehension skills & 0.544 \\
\hline 15. & Skills to evaluate and reduce the complexity of program unit & 0.590 \\
\hline 16. & Cost and benefit analysis of programming language & 0.662 \\
\hline 17. & Comparative study of programming languages & 0.582 \\
\hline \multicolumn{3}{|c|}{ Database Instructors } \\
\hline 18. & Skills and knowledge of databases & 0.962 \\
\hline 19. & Knowledge of database management systems & 0.884 \\
\hline 20. & Commercial programming skills in databases & 0.725 \\
\hline 21. & $\begin{array}{l}\text { Commercial programming skill for development of front-end appli- } \\
\text { cations of databases }\end{array}$ & 0.480 \\
\hline 22. & Commercial and non-commercial skills of database administration & 0.586 \\
\hline 23. & Command over distributed databases & 0.642 \\
\hline 24. & Skills of exploration of knowledge from databases & 0.442 \\
\hline 25. & $\begin{array}{l}\text { Practical knowledge about behavior of various DBMS (RDBMS, } \\
\text { ORDBMS) }\end{array}$ & 0.764 \\
\hline 26. & Analytical Skills & 0.500 \\
\hline 27. & Spoken Language Skills & 0.390 \\
\hline 28. & Knowledge of specific database query language & 0.684 \\
\hline 29. & Knowledge of Web Engineering on databases & 0.750 \\
\hline 30. & $\begin{array}{l}\text { Knowledge of diagrammatic representat ion of relations within data- } \\
\text { bases }\end{array}$ & $\mathbf{0 . 8 8 0}$ \\
\hline 31. & Knowledge of replication in databases & 0.568 \\
\hline 32. & Knowledge of File systems in comparison with databases & 0.472 \\
\hline 33. & Theoretical and practical skills on intelligent databases & 0.640 \\
\hline 34. & Knowledge about spatial databases & 0.444 \\
\hline 35. & Research oriented methodologies & 0.448 \\
\hline \multicolumn{3}{|c|}{ Computer Ne tworks In structors } \\
\hline 36. & Knowledge of physical media involved in Computer Networks & 0.575 \\
\hline 37. & Knowledge of Network topologies & 0.648 \\
\hline 38. & Knowledge of standards defined in Computer Networks & 0.826 \\
\hline 39. & Knowledge of Analog and digital signal processing & 0.800 \\
\hline 40. & Knowledge of Data communication terminologies & 0.754 \\
\hline 41. & $\begin{array}{l}\text { Knowledge of Operating systems involved in Networks at applica- } \\
\text { tion level }\end{array}$ & 0.728 \\
\hline 42. & $\begin{array}{l}\text { Knowledge of operat ing systems involved in net works at system } \\
\text { level }\end{array}$ & 0.546 \\
\hline 43. & Knowledge of Network configurations & 0.700 \\
\hline 44. & Knowledge of directory/user services in Networks & 0.848 \\
\hline 45. & Troubleshooting in Networks & 0.902 \\
\hline 46. & Knowledge of MAN/WAN configurations & 0.532 \\
\hline 47. & Useful applications after installations and orientation of Networks & 0.322 \\
\hline 48. & Practical network establishment & 0.556 \\
\hline 49. & Network administration & 0.886 \\
\hline 50. & Spoken Language skills & 0.542 \\
\hline
\end{tabular}




\begin{tabular}{||l|l|l|}
\hline 51. & Comparat ive study of various networks & 0.442 \\
\hline 52. & Network algorithms & $\mathbf{0 . 8 9 2}$ \\
\hline 53. & Network programming & $\mathbf{0 . 8 4 4}$ \\
\hline 54. & Protocols in Computer Networks & 0.684 \\
\hline
\end{tabular}

The boldface values in the Table 2 are showing that the factors are critical according to the selected threshold. There were a few values quite near to the threshold so those values were also kept in mind during the development of curriculum but they are not ranked as critical.

The critical skills for computer academicians had been identified on the basis of obtained results. After the identification of skills, three different courses are proposed for academicians of Computer Programming, Databases and Computer Networks respectively. The personnel in Pakistani educational institutions are hired on two different merit criteria: (1). Specialist of the particular domain, (2). Teaching Assistants.

The three proposed courses are quite appropriate for specialists of domains but there should be a generic training course for teaching assistants who are expected to be skillful in a broad domain.

\section{Course Structure for Subject Specialists}

On the basis of critical factors extracted from the obtained results presented in Table 2, the following topics are included in the course offered to Subject Specialists (Professors/ Assistant professors) of Computer Programming.

First column in Table 3 shows the critical skills needed for specific subject area and second column propose the subject courses from which special topics can be selected for preparing the curriculum of the course.

In Table 3:

h.o.p = hands on practice session (practical work/ laborat ory work)

$\mathrm{p} . \mathrm{w}=$ project work

$\mathrm{c} . \mathrm{w}=$ course work (theoretical)

\begin{tabular}{|c|c|c|c|}
\hline Critical Skill & Special topics from & \multicolumn{2}{|c|}{ Duration $=48$ weeks } \\
\hline \multicolumn{4}{|l|}{ Computer Programming } \\
\hline $\begin{array}{l}\text { Mathematical/Logical compu- } \\
\text { tations }\end{array}$ & $\begin{array}{l}\text { Discrete Mathematics } \\
\text { (c.w }=10 \text { hours), } \\
\text { Logic \& computation } \\
\text { (c. } w=20 \text { hours), } \\
\text { Statistical computations } \\
\text { (c. } w=10 \text { hours }+ \text { h.o.p }=5 \\
\text { hours) }\end{array}$ & 3 weeks & 45 hours \\
\hline $\begin{array}{l}\text { Data Structures \& its mapping } \\
\text { in memory }\end{array}$ & $\begin{array}{l}\text { Data structures } \\
(\mathrm{c} . \mathrm{w}=20 \text { hours }+ \text { h.o.p. }=5 \text { hours } \\
+\mathrm{p} \cdot \mathrm{w}=10 \text { hours }) \\
\text { Logic \& Comput ation } \\
\text { (c. } \mathrm{w}=10 \text { hours })\end{array}$ & 3 weeks & 45 hours \\
\hline
\end{tabular}


Critical Skills for Computer Academicians

\begin{tabular}{|c|c|c|c|}
\hline P Pseudo Code development & $\begin{array}{l}\text { Algorithms }(\mathrm{c} . \mathrm{w}=10 \text { hours }) \\
\text { Data Structures } \\
\text { (c.w }=5 \text { hours) } \\
\text { Analysis of Algorithms } \\
\text { (c. } \mathrm{w}=10 \text { hours }+ \text { h.o.p. }=5 \\
\text { hours) }\end{array}$ & 2 weeks & 30 hours \\
\hline Programming Constructs & $\begin{array}{l}\text { Theory of programming lan- } \\
\text { guage } \mathrm{s}(\mathrm{c} . \mathrm{w}=5 \text { hours) } \\
\text { Object-orient ed programming } \\
(\mathrm{c} . \mathrm{w}=10 \text { hours }+ \text { h.o.p }=5 \text { hours } \\
+ \text { p.w }=10 \text { hours) } \\
* * \text { Project should be done from } \\
\text { both OOP and RA } \\
\text { Rapid applications } \\
\text { (c. } \mathrm{w}=5 \text { hours }+ \text { h.o.p }=15 \\
\text { hours) }\end{array}$ & 3 weeks & 45 hours \\
\hline Miscellaneous & $\begin{array}{l}\text { Theory of computation } \\
\text { (c.w }=10 \text { hours) } \\
\text { Theory of automata } \\
\text { (c.w }=10 \text { hours) } \\
\text { Problem areas in Computer } \\
\text { Sciences (c.w }=10 \text { hours) }\end{array}$ & 2 weeks & 30 hours \\
\hline \multicolumn{4}{|l|}{ Databases } \\
\hline General Databases & $\begin{array}{l}\text { Introduction to databases } \\
\text { (c. } w=5 \text { hours }+ \text { h.o.p }=10 \\
\text { hours) } \\
\text { Database models } \\
\text { (c. } w=5 \text { hours) } \\
\text { Types of databases } \\
\text { (c. } w=10 \text { hours) }\end{array}$ & 2 weeks & 30 hours \\
\hline$\overline{\mathrm{DBMS}}$ & $\begin{array}{l}\text { General concept } \mathrm{s} \\
(\mathrm{c} . \mathrm{w}=5 \text { hours }) \\
\text { Relationships }(\mathrm{c} . \mathrm{w}=5 \text { hours }) \\
\text { Administration } \\
(\mathrm{c} . \mathrm{w}=5 \text { hours }+ \text { h.o.p }=10 \text { hours } \\
+ \text { p.w }=5 \text { hours })\end{array}$ & 2 weeks & 30 hours \\
\hline Commercial programming & $\begin{array}{l}\text { SQL }(\mathrm{c} \cdot \mathrm{w}=5 \text { hours }+ \text { h.o.p }=10 \\
\text { hours) } \\
\text { SQL Server } \\
\text { (c.w }=5 \text { hours }+ \text { h.o.p }=10 \\
\text { hours) MySQL (h.o.p }=10 \\
\text { hours) } \\
\text { ERWIN (c. } \mathrm{w}=2 \text { hours }+ \text { h.o.p }= \\
3 \text { hours) }\end{array}$ & 3 weeks & 45 hours \\
\hline
\end{tabular}




\begin{tabular}{|c|c|c|c|}
\hline $\begin{array}{l}\text { Behavior of different DBMS's } \\
\text { (RDBMS, ORDBMS) }\end{array}$ & $\begin{array}{l}\text { Database management sys- } \\
\text { tems (c.w }=5 \text { hours }+ \text { h.o.p }=10 \\
\text { hours }) \\
\text { Object-Oriented databases } \\
\text { (c. } w=5 \text { hours }+ \text { h.o.p }=5 \text { hours) } \\
\text { Data modeling } \\
\text { (c. } w=5 \text { hours) }\end{array}$ & 2 weeks & 30 hours \\
\hline $\begin{array}{l}\text { Web Engineering on Data- } \\
\text { bases }\end{array}$ & $\begin{array}{l}\text { Databases on web } \\
(\mathrm{c} . \mathrm{w}=10 \text { hours }+ \text { h.o.p }=10 \\
\text { hours }) \text { Online int eractive data- } \\
\text { base management } \\
(\mathrm{c} . \mathrm{w}=10 \text { hours }+ \text { h.o.p }=5 \text { hours } \\
+ \text { p.w }=10 \text { hours })\end{array}$ & 3 weeks & 45 hours \\
\hline $\begin{array}{l}\text { Diagrammatic representation } \\
\text { of relations in databases }\end{array}$ & $\begin{array}{l}\text { Ent ity-relationships } \\
\text { (c.w }=5 \text { hours) } \\
\text { ERWIN, VISIO } \\
\text { (h.o.p }=5+5 \text { hours) }\end{array}$ & 1 week & 15 hours \\
\hline Miscellaneous & $\begin{array}{l}\text { Performance tuning and re- } \\
\text { covery of dat abases } \\
\text { (c. } w=10 \text { hours }+ \text { h.o.p }=5 \\
\text { hours }) \\
\text { Federated database manage- } \\
\text { ment systems } \\
\text { (c. } w=5 \text { hours }+ \text { h.o.p }=5 \text { hours } \\
+ \text { p.w }=5 \text { hours })\end{array}$ & 2 weeks & 30 hours \\
\hline \multicolumn{4}{|l|}{ Computer Ne tworks } \\
\hline $\begin{array}{l}\text { Defined standards in Com- } \\
\text { puter Net works }\end{array}$ & $\begin{array}{l}\text { IEEE standards } \\
(\mathrm{c} . \mathrm{w}=5 \text { hours }) \\
\text { Ethernet } \\
\text { (c. } \mathrm{w}=10 \text { hours }+\mathrm{p} . \mathrm{w}=5 \text { hours }) \\
\text { FDDI standards } \\
\text { (c. } \mathrm{w}=5 \text { hours) } \\
\text { OSI standards } \\
\text { (c. } \mathrm{w}=10 \text { hours }+ \text { h.o.p }=10 \\
\text { hours) }\end{array}$ & 3 weeks & 45 hours \\
\hline $\begin{array}{l}\text { Analog \& Digital signal proc- } \\
\text { essing }\end{array}$ & $\begin{array}{l}\text { Digital signal processing } \\
(\mathrm{c} . \mathrm{w}=10 \text { hours }+\mathrm{p} . \mathrm{w}=5 \text { hours }) \\
\text { Analog signal processing } \\
(\mathrm{c} . \mathrm{w}=10 \text { hours }+\mathrm{p} . \mathrm{w}=5 \text { hours })\end{array}$ & 2 weeks & 30 hours \\
\hline Data communication & $\begin{array}{l}\text { Computer Networks } \\
(\mathrm{c} . \mathrm{w}=15 \text { hours }+ \text { h.o.p }=15 \\
\text { hours }+\mathrm{p} . \mathrm{w}=5 \text { hours }) \\
\text { Data communication stan- } \\
\text { dards and methodo logies } \\
\text { (c. } \mathrm{w}=10 \text { hours) }\end{array}$ & 3 weeks & 45 hours \\
\hline
\end{tabular}


Critical Skills for Computer Academicians

\begin{tabular}{|c|c|c|c|}
\hline $\begin{array}{l}\text { Knowledge of Operating sys- } \\
\text { tems }\end{array}$ & $\begin{array}{l}\text { Modern Operating systems } \\
\text { concepts } \\
\text { (c.w }=10 \text { hours) } \\
\text { Applicat ions of Operat ing sys- } \\
\text { tems (h.o.p }=5 \text { hours) } \\
\text { Guide to operat ing systems } \\
\text { (LINUX) } \\
\text { (c. } w=5 \text { hours }+ \text { h.o.p }=10 \\
\text { hours) }\end{array}$ & 2 weeks & 30 hours \\
\hline Network configurations & $\begin{array}{l}\text { Network structures and con- } \\
\text { figurations } \\
\text { (c. } w=5 \text { hours) } \\
\text { Networking Essentials } \\
\text { (c. } w=5 \text { hours }+ \text { h.o.p }=5 \text { hours) }\end{array}$ & 1 week & 15 hours \\
\hline Directory/User services & $\begin{array}{l}\text { Microsoft windows } 2000 \\
\text { server and professional } \\
\text { (h.o.p }=15+15 \text { hours) }\end{array}$ & 2 weeks & 30 hours \\
\hline Troubleshooting & $\begin{array}{l}\text { Microsoft windows } 2000 \\
\text { server and professional, } \\
\text { MCSE guide } \\
\text { (h.o.p }=8+7 \text { hours) }\end{array}$ & 1 weeks & 15 hours \\
\hline Administration & $\begin{array}{l}\text { LAN administration } \\
\text { (h.o.p }=5 \text { hours) } \\
\text { Microsoft windows } 2000 \\
\text { server and professional } \\
\text { (h.o.p }=5+5 \text { hours) }\end{array}$ & 1 week & 15 hours \\
\hline Network algorithms & $\begin{array}{l}\text { Algorithms for Computer } \\
\text { Networks } \\
(\text { c. } w=5 \text { hours }+ \text { h.o.p }=5 \text { hours } \\
+ \text { p.w }=10 \text { hours }) \\
\text { Network system development } \\
\text { (c. } w=5 \text { hours }+ \text { h.o.p }=5 \text { hours) }\end{array}$ & 2 weeks & 30 hours \\
\hline Network programming & $\begin{array}{l}\text { Guide to Computer Net work } \\
\text { programming, Socket pro- } \\
\text { gramming } \\
\text { (c. } \mathrm{w}=5 \text { hours }+ \text { h.o.p }=5 \text { hours }) \\
\text { JAVA as network program- } \\
\text { ming language } \\
(\mathrm{c} . \mathrm{w}=5 \text { hours }+ \text { h.o.p }=5 \text { hours } \\
+ \text { p.w }=10 \text { hours })\end{array}$ & 2 weeks & 30 hours \\
\hline
\end{tabular}

The work can be extended to include full-fledge curriculum on the grounds of above-mentioned structure. This course structure will work for the subject specialists while most of the staff at undergraduate level and teaching assistants needs to have the int egrated skills in all three subdomains. So there should be a separate preparatory course for the staff employed at this level. 


\section{Course Structure for Teaching Assistants}

To prepare course structure for these teaching assistants following methodology is devised.

The websites, course brochures and interviews with dean/head of departments of various wellreputed IT/Engineering based inst it utions and HEC literat ure review and curriculum proposed by Higher Education Commission in 2004 made it possible to inference the following facts.

- Higher Education Commission Pakistan made four classes of subjects in BS program of computing.

- These classes are Core Subjects, Elective Subjects, university electives and supporting areas.

- Core subjects included; Computing, Programming Fundamentals, Object Oriented Programming, Data Structures \& Algorithms, Discrete structures, Dat abase systems, Digital Logic \& Design, Operat ing Systems, Communication \& Networks, Soft ware Project Design.

- It has been observed that $82.5 \%$ well-reputed and HEC recognized universities/institutions included Computing, Programming Fundamentals, and Object Oriented Programming, Digital Logic \& Design, Operating Systems and Data structures as core subjects in the curriculum of BS in Computer Sciences.

- Computer Sciences Accreditation Commission of Computing Sciences Accreditation Board (CSAC/CSAB) (2000) designed curriculum for Computer Sciences in which 40 hours for Computer subjects, 30 hours for Mathematics \& Science and 30 hours for humanities, social sciences and other disciplines were included. 62\% universities/ Inst it utions in Pakistan follow the similar convention (Division of weight age in hours is different).

- William Burkett constructed a workable Computer Sciences curriculum (2002) in which he identified general characteristics of Computer Sciences graduates. These characteristics are;

- System-level perspective

- Appreciation of the interplay between theory and practice

- Familiarity with common themes

- Significant project experience

- Adaptability

- The education in Computer Sciences needs more attention because of its fast growth. The rapidly changing technology in IT world make the skills of IT professionals obsolete after certain period of time. These professionals should be skillful in research methodologies to adopt the changing scenario in an efficient manner. So it had also been concluded that the computer academicians should have the ability to make the students well aware of research methodologies and of adaptability to the advancements in technology.

The mentioned conclusions and the survey through online questionnaire derived the critical skills for teaching assistants shown in Table 4. 


\begin{tabular}{|c|c|c|c|}
\hline \multicolumn{4}{|c|}{ Table 4. Proposal of Subject agains t e ach critical skill (TA) } \\
\hline \multirow{2}{*}{$\begin{array}{l}\text { Critical Skill } \\
\text { Programming Skills }\end{array}$} & \multirow[b]{2}{*}{$\begin{array}{l}\text { Spe cial topi cs from } \\
\text { Discrete Mathematics } \\
\text { (c. } w=10 \text { hours), } \\
\text { Logic \& computation } \\
\text { (c. } \mathrm{w}=20 \text { hours), } \\
\text { Statistical computations } \\
\text { (c. } w=10 \text { hours }+ \text { h.o.p }=5 \\
\text { hours) }\end{array}$} & \multicolumn{2}{|c|}{ Duration $=38$ weeks } \\
\hline & & 3 weeks & 45 hours \\
\hline $\begin{array}{l}\text { Data Structures \& its mapping } \\
\text { in memory }\end{array}$ & $\begin{array}{l}\text { Data structures } \\
(\mathrm{c} . \mathrm{w}=15 \text { hours }+ \text { h.o.p. }=5 \text { hours } \\
+\mathrm{p} \cdot \mathrm{w}=10 \text { hours })\end{array}$ & 2 weeks & 30 hours \\
\hline Programming Constructs & $\begin{array}{l}\text { Theory of programming lan- } \\
\text { guage } \mathrm{s}(\mathrm{c} . \mathrm{w}=10 \text { hours }) \\
\text { Programming in } \mathrm{C} / \mathrm{C}++ \\
(\mathrm{c} . \mathrm{w}=10 \text { hours }+ \text { h.o.p }=15 \\
\text { hours }+ \text { p.w }=10 \text { hours })\end{array}$ & 3 weeks & 45 hours \\
\hline General Databases & $\begin{array}{l}\text { General concepts of Databases } \\
(\mathrm{c} . \mathrm{w}=5 \text { hours }+ \text { h.o.p }=10 \\
\text { hours) } \\
\text { Types of databases } \\
\text { (c. } \mathrm{w}=10 \text { hours }+ \text { h.o.p }=5 \\
\text { hours) }\end{array}$ & 2 weeks & 30 hours \\
\hline DBMS & $\begin{array}{l}\text { Database management and } \\
\text { administration } \\
(\mathrm{c} . \mathrm{w}=15 \text { hours }+ \text { h.o.p }=15 \\
\text { hours }+ \text { p.w }=15 \text { hours })\end{array}$ & 3 weeks & 45 hours \\
\hline $\begin{array}{l}\text { Practical experience in query } \\
\text { and development tools }\end{array}$ & $\begin{array}{l}\text { SQL } \\
\text { (h.o.p }=15 \text { hours) } \\
\text { SQL Server } \\
\text { (h.o.p }=15 \text { hours) } \\
\text { MS ACCE SS } \\
\text { (h.o.p }=15 \text { hours) }\end{array}$ & 3 weeks & 45 hours \\
\hline Computer Operations & $\begin{array}{l}\text { Computer Architecture } \\
(\mathrm{c} . \mathrm{w}=10 \text { hours }+ \text { h.o.p }=10 \\
\text { hours }) \\
\text { Digital Logic } \& \text { Design } \\
(\mathrm{c} . \mathrm{w}=10 \text { hours }+ \text { h.o.p }=5 \text { hours } \\
+ \text { p.w }=10 \text { hours })\end{array}$ & 3 weeks & 45 hours \\
\hline $\begin{array}{l}\text { Database Models including } \\
\text { diagrammatic representation }\end{array}$ & $\begin{array}{l}\text { ERWIN } \\
\text { (h.o.p }=5 \text { hours) } \\
\text { Relationships in Databases } \\
\text { (c. } \mathrm{w}=5 \text { hours }+ \text { h.o.p }=5 \text { hours) }\end{array}$ & 1 week & 15 hours \\
\hline Networking Essentials & $\begin{array}{l}\text { MCSE guide for Computer } \\
\text { Networks } \\
\text { (c. } w=10 \text { hours }+ \text { h.o.p }=20 \\
\text { hours) }\end{array}$ & 2 weeks & 30 hours \\
\hline
\end{tabular}




\begin{tabular}{|c|c|c|c|}
\hline Networks establishments & $\begin{array}{l}\text { Microsoft windows } 2000 \\
\text { server and professional } \\
\text { (h.o.p }=15+15 \text { hours) }\end{array}$ & 2 weeks & 30 hours \\
\hline Research Methodologies & $\begin{array}{l}\text { Research Methods } \\
(\mathrm{c} . \mathrm{w}=10 \text { hours }+\mathrm{p} \cdot \mathrm{w}=10 \\
\text { hours }) \\
\text { Adopting new technology } \\
(\mathrm{c} . \mathrm{w}=10 \text { hours) }\end{array}$ & 2 weeks & 30 hours \\
\hline Computer Electronics & $\begin{array}{l}\text { Digital fundamentals for com- } \\
\text { puter systems } \\
\text { (c. } w=10 \text { hours }+ \text { h.o.p }=5 \\
\text { hours) } \\
\text { Digital Logic \& Design } \\
\text { (c. } w=10 \text { hours }+ \text { h.o.p }=5 \\
\text { hours) }\end{array}$ & 2 weeks & 30 hours \\
\hline Mathematics & $\begin{array}{l}\text { Discrete mathematics } \\
\text { (c. } w=10 \text { hours) } \\
\text { Calculus } \\
\text { (c. } w=10 \text { hours) } \\
\text { Business mathematics } \\
\text { (c. } w=10 \text { hours) }\end{array}$ & 2 weeks & 30 hours \\
\hline Business Education & $\begin{array}{l}\text { Business communication } \\
\text { (c.w }=10 \text { hours) } \\
\text { Accounting } \\
\text { (c.w }=10 \text { hours) } \\
\text { IT in business } \\
\text { (c. } w=10 \text { hours) }\end{array}$ & 2 weeks & 30 hours \\
\hline Software applied processing & $\begin{array}{l}\text { Soft ware Engineering } \\
(\mathrm{c} . \mathrm{w}=10 \text { hours }+\mathrm{p} \cdot \mathrm{w}=5 \text { hours }) \\
\text { SAD } \\
(\mathrm{c} . \mathrm{w}=10 \text { hours }+\mathrm{p} \cdot \mathrm{w}=5 \text { hours }) \\
\text { SAP } \\
(\mathrm{c} . \mathrm{w}=5 \text { hours }+ \text { h.o.p }=10 \\
\text { hours })\end{array}$ & 3 weeks & 45 hours \\
\hline Project & $\begin{array}{l}\text { Proposal and Thesis } \\
\text { (p.w }=45 \text { hours) }\end{array}$ & 3 weeks & 45 hours \\
\hline
\end{tabular}

\section{Conclusions}

The research identified and verified the critical skills for Computer academicians. For subject specialists, more emphasis should be placed on conceptual knowledge while the teaching assistants need fundamental conceptual as well as practical knowledge of the domain.

Computer Programming, Database development and Computer Networks are the three rapidly growing areas for Computer professionals in IT industry of Pakistan so the academicians need research and development skills in these three areas. The skills with highest critical values are knowledge of programming constructs and mathematical computations for programming instructors, skills/knowledge of databases and DBMS for Dat abase instructors and Net work trouble- 
shooting, administration and algorithms for computer Networks instructors. The work can be extended to include full fledge curriculum for the proposed course which should be quite specific and domain-focused.

\section{References}

Braun, G. F., Tesch, D., \& Skeldon, R. (2005). The student-professor research relationship: Examining IS employer skills expectations. Department of In formation Systems, Xavier University Cincinnati, OH 45207, USA

Burkett, W. (2002). Constructing a workable computer information science/computer science curri culum: A template for developing a cross-discipline model. Journal of Information Technology Education, 1(1), 65-76. Retrieved from http://jite.org/documents/Vol1/v1n1p065-076.pdf

Byrd, T. A., \& Turner, D. E. (2001). An exploratory analysis of the value of the skills of IT personnel: Their relationship to IS. Decision Sciences, 32(1), 21-55.

Cappel, J. J. (2002). Entry-level IS job skills: A survey of employers. Journal of Computer Information Systems, 42(2), 76-82.

Computing Curricula 2001. (2001). Computer Society of the Institute for Electrical and Electronic Engineers (IEEE-CS) and the Association for Computing Machinery (ACM). Retrieved from www.acm.org/sigcse/cc2001

Criteria for Accrediting Programs in Computer Science in the United States. (2000). Computer Science Accreditation Commission of the Computing Sciences Accreditation Board, January 2000, Version 1.0. Retrieved from http://www.cse. fau.edu/ roy/csab97/criteria962.html - P2

Freeman, P., \& Aspray, W. (1999). The supply of information technology workers in the United States. Washington, DC: Computing Research Association.

Higher Education Commission, Pakistan. (2004). Class-wise list of universities. Retrieved November 20, 2004 from http://www.hec.gov.pk/quality/University\%20Ranking\%20Criteria.htm

Higher Education Commission, Pakistan. (2004). Curriculum of computer sciences, software engineering and information technology, pp.13-23. Retrieved from http://www.hec.gov.pk/new/AcademicA ffairs/Curricul am Revision/download/2005/CS IT SE.pdf

Hingorani, K. K., \& Sankar, C. S. (1995). Entry level MIS jobs: Industry expectations versus academic preparation. Journal of Computer Information Systems, 35(4), 18-27.

Instructional Technology Guiding Rigorous Academics and Teaching Excellence (INTEGRATE), A working group of the Delaware Center for Educational Technology, (DCET) (2005). Computer skills growth chart. Retrieved from http://www.dcet.k12.de.us/instructional/skills/

Jacobs, S. J. (1973). Cognitive predictors of success in computer programmer training. Proceedings of the Eleventh Annual Computer Personnel Research Conference, pp. 98 - 110.

Kelegai, L., \& Middleton, M. (2002). Information technology education in Papua New Guinea: Cultural, economic and political influences. Journal of Information Technology Education, 1(1), 11-24. Retrieved from http://jite.org/documents/Vol1/v1n1p011-024.pdf

Kim, Y., Shim, S. J., \& Yoon, K. P. (1999). Bridging the gap between practitioner-edu cator perceptions of key IS issues for effective implementation of IS curriculum. Proceedings of 1999 IRMA International Conference, Hershey, PA. pp. 513-518.

Lee, D. M. S., Trauth, E., \& Farwell, D. (1999). Critical skills and knowledge requirements of IS professionals: A joint academic/industry investigation. MIS Quarterly, 19, 313-340.

Liu, X., Kiu, L.C., Koong, K.S., \& Lu, J. (2003). An examination of job skills posted on internet databases implications for information systems degree programs. Journal of Education for Business, 78(4), 191196. 
Maglitta, J. (1996, February 19). IS schools: Need improvement. Computerworld, 30(8), 78-83.

Maier, J. L., Clark, W. J., \& Remington, W. S. Jr. (1998). A longitudinal study of the management inform ation systems (MIS) job market. Journal of Computer Information Systems, 39(1), 37-41.

Miller, R. A., \& Luse, D. W. (2004). Advancing the IS curricula: The identification of important communication skills needed by IS staff during systems development. Journal of Information Technology Education, 3, 117-131. Retrieved from http://iite.org/documents/Vol3/v3p117-131-107.pdf

Ministry of Information technology, Government of Pakistan-IT and Telecom Division. (2004). Executive Summary-IT policy. Retrieved on April 21, 2004, from http://www.pakistan.gov.pk/divisions/ContentInfo.jsp?DivID=9\&cPath=81 85 237\&ContentID=380

Nicolai, B. J. (2004). IS database curriculum information systems or information technology: An accreditation dilemma. Proceedings of ISECON 2004, 21 (Newport) EDSIG. P 1-9.

Noll, C. L., \& Wilkins, M. (2002). Critical skills of IS professionals: A model for curriculum development. Journal of Information Technology Education, 1(3), 143-154. Retrieved from http://jite.org/documents/Vol1/v1n3p143-154.pdf

Smith L. I. (2002). A tutorial on principal component analysis. Retrieved from http://www.snl.salk.edu/ shlens/pub/notes/pca.pdf

Srinivasan, S., Guan, J., \& Wright, A. L. (1999). A new CIS curriculum design approach for the 21 st century. Journal of Computer Information Systems. 39(3), 99-106.

\section{Biographies}

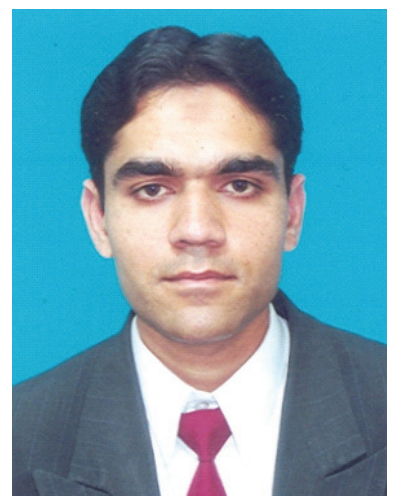

M. Shaheen Kh an Tanoli is research associate in University of Engineering \& T echnology Lahore, Pakistan. He has completed his Masters in Sciences (Computer Sciences) in the year 2007 and been awarded Gold-Medal in acceptance of his distinction in academics. He got Masters Degree in Computer Sciences with Gold Medal from University of Peshawar in 2003. Muhammad Shaheen Khan has number of publications in journals, all overthe world. He has now been enrolled in $\mathrm{PhD}$ (Computer Sciences) with the grant of scholarship from HEC, Pakistan. His research interests include Data mining, Object-Oriented Software Systems, Soft ware Metrics, Operations Research and Computer Education.

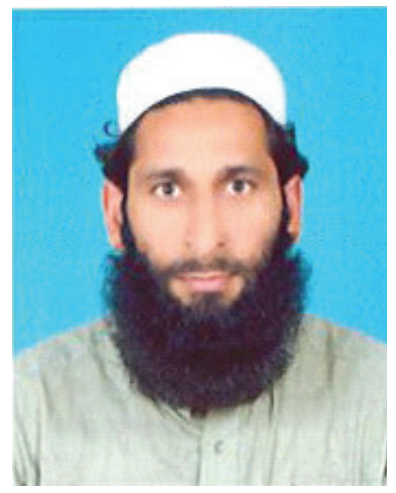

Zahoor ur Rehm an is research associate (PhD (CS)) in University of Engineering \& Technology Lahore, Pakistan. He has completed his Masters in sciences (Computer Sciences) in the year 2007 with the grant of scholarship from HEC, Pakistan. His research interests include Data Mining, Disaster Management and Computer Education. 